\title{
OPTIMIZED EARTHWORK PLANNING METHODOLOGY FOR LAND DEVELOPMENT PROJECTS
}

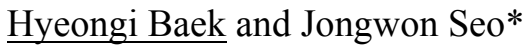 \\ Department of Civil and Environmental Engineering, Hanyang University, Seoul, Korea \\ *Corresponding author (jseo@hanyang.ac.kr)
}

\begin{abstract}
An earthwork for land development projects, which possesses around $20 \%$ of the total project cost, consists mainly of simply repetitive tasks such as loading, hauling, dumping, and returning and depends largely on heavy construction machines. The goal of earthwork planning is to minimize the project cost and duration by determining soil allocation, equipment configuration, and haul route. Due to the absence of programs or guidelines for earthwork planning, planners rely heavily on their experiences for planning. Subjective decisions can cause problems such as repetitive works, difficulties in finding solutions, and considerable working time. This paper presents the earthwork planning model using Simulated Annealing algorithm which is a stochastic optimization algorithm. Interviews with planners were conducted to investigate current earthwork planning process and planners' heuristics. It is found that the objective of earthwork planning is to minimize earthwork cost by balancing soil volume and minimizing hauling distance. In order to reflect collected planners' rules of thumb, three objective functions (balancing cut-fill volume, compactness, and constructability) were framed and case study was conducted to verify the applicability of the proposed model.
\end{abstract}

Keywords: Earthwork Planning, Optimization, Simulated Annealing Algorithm, Land Development Project

\section{INTRODUCTION}

Earthwork tasks for site development projects repeat simple works; loading-hauling-dumping-returning. When planning earthworks, planners depend on their experiences due to the lack of guidelines or planning tools. This paper proposes an earthwork planning model which aims to assist planners in finding the optimized solution.

This paper consists of three sections. First, planning process and planners' heuristics were investigated through literature reviews and interviews with planners. Second, the model was established using Simulated Annealing (SA) algorithm. Finally, case study was conducted to verify the applicability and usability of the model.

\section{EARTHWORK PLANNING}

Current earthwork planning process and planners' heuristics or "rules of thumb" were investigated. In Korea, earthwork planners use a program namely DAS provided by Korea Land and Housing Corporation. It divides the field into $4 \mathrm{~m}$ by $4 \mathrm{~m}$ grids, calculates net soil volume, and determines cut and fill areas [1]. Based on the result, planners devise an earthwork plan. By reviewing literatures [2], [3], [4] and interviewing with planners, it was established that the goal of planning is to balance cut-fill volume and minimize the hauling cost. When estimating hauling cost, planners use the average hauling distance.

$$
\begin{aligned}
& \frac{\sum_{i=1}^{n} \sum_{j=1}^{m} D_{i j} \times Q_{i j}}{\sum_{i=1}^{n} \sum_{j=1}^{m} Q_{i j}} \\
& \text { where } D_{i j} \text { : hauling distance from cut } i \text { to fill } j \\
& Q_{i j}: \text { soil quantity from cut } i \text { to fill } j
\end{aligned}
$$

Equation (1)

\section{EARTHWORK PLANNING MODEL}

Earthwork planning model was established using Matlab due to its merit to form the field into a shape of a matrix and the frame of earthwork planning model was configured in three parts.

First, based on imported data from DAS, districting algorithm generates a new alternative. It was framed to divide the site into fixed number of districts and to avoid 
from generating empty or discontinuous districts using equation (2). It starts from $(1,1)$, finds cells located at the boundary of each district, and then decides to change the cell by generating random number.

$$
\sum_{\substack{i \in D_{j} \\ x_{i}=0 \text { or } 1}} x_{i} \geq 1
$$

Equation (2)

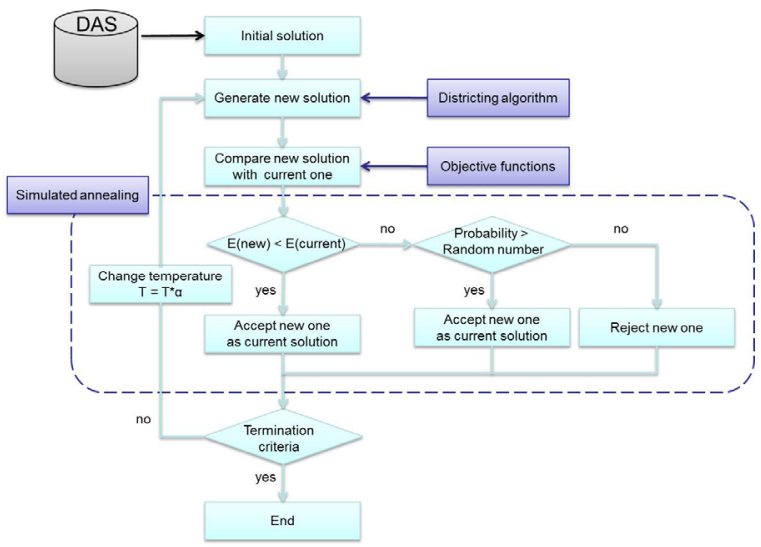

Fig. 1 Diagram of earthwork planning model

Second, the model evaluates new solution using three objective functions based on investigated heuristics; compactness, balancing soil volume, and constructability. Compactness was famed to avoid odd-shaped districts and to make the hauling distance short. The sum of soil quantities in absolute value was formulated to balance cutfill volume. Last objective function is constructability aiming to prevent soil from leaning to one side. In this function fuzzy logic was introduced according to soil types.

\begin{tabular}{|c|c|}
\hline Function & Formula \\
\hline $\begin{array}{c}\text { Compact- } \\
\text { ness }\end{array}$ & 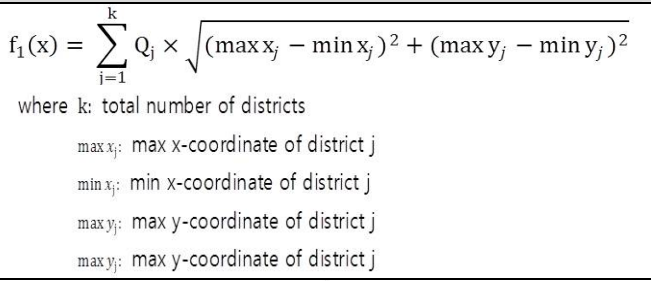 \\
\hline $\begin{array}{c}\text { Balancing } \\
\text { soil } \\
\text { volume }\end{array}$ & $\begin{array}{c}\qquad f_{2}(x)=\sum_{j=1}^{k}\left|Q_{j}\right| \\
\text { subject to } Q_{j}=\sum_{i \in D_{j}} q_{i}, D_{j}=\left\{i \mid x_{i}=j\right\} \\
\text { where } q_{i} \text { : the amount of soil quantities to be moved in node } i\end{array}$ \\
\hline $\begin{array}{c}\text { Construct } \\
\text { abillity }\end{array}$ & $\begin{array}{c}\mathrm{f}_{3}(\mathrm{x})=\sum_{\mathrm{j}=1}^{\mathrm{k}} \frac{\left|\mathrm{C}_{\mathrm{j}}-\overline{\mathrm{C}}\right|}{\overline{\mathrm{C}}} \\
\text { subject to } \mathrm{C}_{\mathrm{j}}=\sum_{\mathrm{t}-1}^{\mathrm{T}} \sum_{\mathrm{i} \in \mathrm{D}_{\mathrm{j}}} \mathrm{f}_{\mathrm{t}} \mathrm{q}_{\mathrm{it}} \\
\text { where } \mathrm{f}_{\mathrm{t}} \text { : fuzzy value according to soil type } \\
\mathrm{q}_{i t} \text { : the amount of soil of type } \mathrm{t} \text { in node } \mathrm{i}\end{array}$ \\
\hline
\end{tabular}

Table. 1 Objective functions
Finally, SA algorithm which is a stochastic optimization algorithm accepts the new solution as current best if new solution has lower value than current best in three functions. If not, it compares the possibility computed using temperature $\mathrm{T}$ with random number to decide to accept or not. As this process progressed, the possibility is getting reduced.

Actual industrial site development design data in forms of 17 by 15 matrix was applied to the model to verify the applicability. For the case study, the maximum number of districts set to 6 , iterations was assigned to 10,000 times, and fuzzy value according to soil type was assigned as follows; soil (0.25), soft rock (0.50), hard rock (0.75). When the number of districts was assigned to 4 , the model presented the best result, $6.27 \mathrm{~m}$ in the average hauling distance using equation (1) which is $14.81 \%$ reduction compared to the original data, $7.36 \mathrm{~m}$.

From testing, it has been shown that the model is able to generate efficient earthwork plans that are comparable to those generated by planners. Although the model is based on several approximations, it will provide better solution to planners compared to current subjective decision.

\section{ACKNOWLEDGEMENT}

This research was supported by a grant from Construction Technology Innovation Program (CTIP) funded by Ministry of Land, Transportation and Maritime Affairs (MLTM) of Korean government.

\section{REFERENCES}

[1] Korea Land and Housing Corporation, DAS Manual, Korea Land and Housing Corporation, 2001.

[2] Son, J., Mattila, K., and Myers, D., "Determination of Haul Distance and Direction in Mass Excavation", Journal of Construction Engineering and Management, Vol. 131(3), pp. 302-309, 2005.

[3] Ji, Y., Borrmann, A., Rank, E., Seipp, F., and Ruzika, S., "Mathematical Modeling of Earthwork Optimization Problems", ICCCBE, 2010.

[4] Easa, S., "Earthwork Allocations with Linear Unit Costs", Journal of Construction Engineering and Management, Vol. 114(4), pp. 641-655, 1987. 